\title{
Albert Memmi, Dictionnaire critique à l'usage des Incrédules
}

Paris, Éditions du Félin, 2002, 375 p.

Michael Löwy

\section{OpenEdition}

\section{Journals}

Édition électronique

URL : http://journals.openedition.org/assr/741

DOI : $10.4000 /$ assr.741

ISSN : 1777-5825

\section{Éditeur}

Éditions de l'EHESS

Édition imprimée

Date de publication : 1 octobre 2002

Pagination : 63-126

ISBN : 2-222-96725-2

ISSN : 0335-5985

\section{Référence électronique}

Michael Löwy, «Albert Memmi, Dictionnaire critique à l'usage des Incrédules », Archives de sciences sociales des religions [En ligne], 120 | octobre - décembre 2002, document 120.75, mis en ligne le 24 octobre 2005, consulté le 21 septembre 2020. URL : http://journals.openedition.org/assr/741 ; DOI : https://doi.org/10.4000/assr.741 
Dictionnaire critique à l'usage des Incrédules. Paris, Éditions du Félin, 2002, 375 p.

Avec le talent littéraire qu'on lui connaît, l'auteur a rassemblé, en forme de dictionnaire, quelques réflexions sur les religions inspirées par le scepticisme et la libre pensée. Spinoza, Voltaire, Marx - curieusement sans discuter de sa critique de la religion Nietzsche et Freud sont parmi les rares auteurs qui ont droit à une entrée, la plupart portant sur des thèmes comme "Apologistes », «Blasphèmes », «Fanatiques », «Intégristes », « Miracles », « Reliques », « Sectes » ou « Zélotes ».

Ici ou là on trouve aussi des notations sociologiques, comme dans l'analyse de l'art en tant que succédané de religion, ou religion sans dieu, mais la plupart des entrées relèvent de la philosophie socimale - voir les entrées «Humanisme », «Libertés » ou «Utopie » - et de la critique anti-religieuse inspirée des Lumières.

Michael Löwy. 